\title{
Lik Antigone v predmoderni literaturi
}

\section{Alen Širca}

Filozofska fakulteta Univerze v Ljubljani, Oddelek za primerjalno književnost in literarno teorijo, Aškerčeva 2, 1000 Ljubljana

https://orcid.org/0000-0001-6292-344X

alen.albin.sirca@ff.uni-lj.si

Razprava tematizira lik Antigone v evropski literaturi, in sicer od antike do konca srednjega veka. Po obdobju klasične grške tragedije (Ajshil, Sofokles, Evripid) je Antigona kot literarna figura doživela najizrazitejšo predelavo v rimski dobi, v Senekovi tragediji Feničanke in Stacijevem epu Tebaida. Vobeh delih je Antigona kljub dokaj aktivni vlogi zaznamovana s stoiškim determinizmom. V srednjem veku je Antigona precej marginalen literarni lik. Nanjo naletimo predvsem v bolj ali manj svobodnih adaptacijah Stacijeve Tebaide, kot sta srednjeveško irsko prozno delo Togail na Tebe (Uničenje Teb) in francoska epska pesnitev Roman de Thèbes (Roman o Tebah). Na sporadične omembe Antigone pa naletimo tudi pri Danteju, Boccacciu in Christine de Pizan. Razprava ugotavlja, da gre v srednjeveški literaturi pri tematizaciji Antigone pogosto za preplet dveh mitoloških likov (in izročil), tebanske in (veliko manj znane) trojanske Antigone. Takšna literarna contaminatio (kontaminacija) obeh Antigon je najvidnejša $v$ Chaucerjevi epski pesnitvi Troilus and Criseyde (Troil in Kresida). Razprava se na koncu dotakne tudi humanistične recepcije Antigone in opozori na hermenevtični problem literarne recepcije Antigone na splošno.

Ključne besede: antična književnost / srednjeveška književnost / tragedija / literarni liki / Antigona / Sofokles / Evripid / Seneka / Stacij / Dante Alighieri / Chaucer, Gottfried / literarna recepcija

Lik Antigone je ena izmed redkih literarnih snovi, ki jo lahko preiskujemo v skoraj neprekinjeni literarni recepciji, ki traja že poltretje tisočletje. Zato je odlikovana tema, ki lahko pokaže, kako se - čisto preprosto rečeno - spreminja čas; je dokument, ki na eni strani razkriva epohalne prelome in menjave občinstva, njihovega okusa, agende, preference, estetiške ideologije, senzibilitete itn., ter na drugi strani silnice kontinuitete in skoraj nespremenljive konstante človeškega duha. Pričujoča razprava si zadaja nalogo, da trasira en del te dolge zgodovine recepcije mita o Antigoni, in sicer na način "panoramske«, "longitudinalne» 
študije, ki v duhovnozgodovinski perspektivi odkriva in interpretira poglavitne postaje literarnih izobličenj Antigone od grške tragedije do konca srednjega veka oz. začetka humanizma v 16. stoletju. Kot bomo videli, gre pri tem vedno že za apropriacijo dolge verige apropriacij oziroma, bolje, za hermenevtično razgrnitev dolge vrste ustvarjalnih prilastitev antičnega mita, ki jih je naplavila (literarna) zgodovina. Zanimala nas bo torej Antigona kot lik, oseba, v konkretnih (in ohranjenih) literarnih delih, ne pa tudi v drugih umetnostih, folklori, arheoloških ostankih ipd. Poleg tega bo največ prostora namenjeno srednjeveški recepciji Antigone, saj je ta v literarnozgodovinskih študijah najmanj poznana in raziskovana. ${ }^{1}$

\section{Antigona v grški tragediji}

Čeprav je Antigona oz. mit o njej kot del širšega sklopa tebanskega mita najverjetneje obstajal pred nastopom grške tragedije, pa se samo ime pojavi šele v začetku 5. stoletja pr. Kr. Prvič jo omenja starogrški zgodovinar in genealog Ferekid Atenski, ki je deloval nekje ob koncu 6. in začetku 5. stoletja. Vsekakor šele s Sofoklovo tragedijo Antigona (441/442 pr. Kr.) dobimo njeno prvo literarno upodobitev in obenem tudi najizvirnejšo in najbolj edinstveno obdelavo tebanskega mita, ki takoj postane tudi klasična. To delo, ki ga navadno prištevamo $\mathrm{k}$ Sofoklovi tebanski trilogiji (skupaj s Kraljem Ojdipom in Ojdipom v Kolonu) prinaša izrazito tematsko novost, saj ni pred Sofoklom, kolikor je znano, nikjer omenjene Kreontove prepovedi Polinejkovega pokopa in, posledično, Antigonine nepokorščine temu zakonu ob sklicevanju na nenapisane in neovrgljive božje zakone (ágrapta kasphalê theôn nómima, verzi 454-455, Sophocles 88). ${ }^{2}$ To, kar je izjemno pomembo, čeprav nekatere sodobne interpretacije na to pozabljajo, je, da je Sofoklova tragedija - in to kljub temu, da bogovi v njej neposredno ne nastopajo - temeljno zaznamovana z ritualno-religioznim obzorjem stare Grčije. To pa, kot opozarja Matic Kocijančič, vodi do spoznanja, da je skrivnost temeljna razsežnost te drame, kar je nadalje tudi ključno za njeno ustrezno literarno vrednotenje: »Ritualna razsežnost Antigoninega dejanja je za sodobnega bralca skrivnostna. Če jo sprej-

${ }^{1}$ To je razvidno že iz dejstva, da zaenkrat ni, vsaj kolikor mi je znano, nobene sintetične študije oz. monografije o srednjeveški recepciji Antigone. Pričujoča razprava je lahko seveda le skromen korak v smeri te dopolnitve.

${ }^{2}$ Prim. Gantarjev prevod: "... neomajne / in nenapisane bogov zakone» (Sofokles 41). 
memo kot táko, imamo pred seboj eno izmed največjih dramskih del vseh časov, če pa želimo skrivnost izkoreniniti, moramo - kot so pokazali najradikalnejši poskusi odgovora na postavljeno vprašanje - pozabiti tradicionalne razlage tega dela, mu odvzeti vsaj eno od temeljnih razsežnosti in izmaličiti njegovo sporočilnost « (Kocijančič, „Kdo« 25). ${ }^{3}$

Gotovo je morala Sofoklova Antigona s svojo drzno nepokorščino moški kraljevski avtoriteti po eni strani šokirati atensko občinstvo, po drugi pa je bila zaradi svoje plemenitosti in neomajne vdanosti htonični religioznosti verjetno tudi izjemno fascinantna. A to ne more docela izčrpati skrivnostnosti in paradoksnosti tragedije: to je zadosten razlog, zakaj je lahko postala - kot to radi rečemo danes - „takojšnja klasika«.

O popularnosti Sofoklove dramske upodobitve Antigone med drugim govori tudi dodatek k Ajshilovi tragediji Sedmerica proti Tebam (Heptà epi Thébas), v kateri je tebanski mit sicer prvič obdelan v okviru tragedije. Dandanašnji je konsenz večine raziskovalcev, da se je ta tragedija izvorno končala pred nastopom Ismene in Antigone, tako da je treba imeti konec drame, kakršna se je ohranila, za dodatek neznanega avtorja, ki je bil kakih petdeset let pozneje dodan prvotnemu Ajshilovem besedilu. Avtor tega dodatka prikazuje Antigono in Ismeno, ki žalujeta za obema bratoma, nato pa Antigona napove, da ne bo spoštovala odloka o prepovedi pokopa Polinejka, ki ga naznani glasnik (Ajshil 61-67). Konec te drame torej po mnenju večine poznavalcev spada že v recepcijo Sofoklove Antigone, se pravi v čas, ko je Sofoklova tragedija že postala klasična (Griffith 7). ${ }^{4}$

Tudi Evripid, tretji veliki traged grške klasične dobe, je vključil Antigono v svoje delo, in sicer v tragedijo Feničanke (Phoinissai), ki je nastala ok. leta 408 pr. Kr. Drama je dobila ime po zboru žensk iz Fenicije, ki jim je tebanska vojna preprečila pot v Delfe in zaradi svojih mitskih vezi s Tebami sočustvujejo s tebansko dinastijo. Evripid je sicer napisal tudi tragedijo z istim naslovom, kot ga ima Sofoklovo delo (Antigona), a se razen nekaj fragmentov ni ohranila.

Za razliko od Sofokla je Antigona v Feničankah stranski lik. Najprej nastopi v drugem prizoru v okviru t. i. teihoskopije (razgledovanja $\mathrm{z}$ obzidja), od koder služabniku poroča, katere junake vidi med argejsko vojsko, ki je prispela pred Tebe (verzi 88-201, Euripides 177-182). Potem pa jo srečamo šele v 15 . prizoru, ko - precej obotavljaje - hiti z

${ }^{3}$ Prim.: »To kompleksno, nestabilno razmerje med božjimi zakoni - zakoni, ki temeljno zavezujejo človeka in jih človek ne postavlja -, voljo ljudstva in legitimnostjo politične oblasti, je ena izmed ključnih teopolitičnih fascinacij antičnih izvirov antigonskega mita" (Kocijančič, Mit o Antigoni 13).

${ }^{4}$ Gl. tudi Kocijančič, Mit o Antigoni 28-29. 
Jokasto na bojno polje preprečit bratomor (verzi 1264-1283, Euripides 228-230). Ta akcija je neuspešna, brata se pobijeta, Jokasta naredi samomor, Antigona pa žaluje za svojimi mrtvimi svojci (19. prizor). V 21. prizoru Kreon prepove pokop Polinejka, Antigona pa se upre in pravi: "Jaz ga pokopljem, kljub prepovedi« (verz 1657, Euripides 244) in napove, da bo šla $v$ izgnanstvo s svojim slepim očetom. V sklepnem prizoru se oba odpravita v Kolon. Očitno je, da se Antigona odpove pokopu Polinejka. ${ }^{5}$

Evripidova Antigona je vendarle bolj kompleksen lik, kot se nemara zdi na prvi pogled, saj na koncu, ko doživi trojno smrt v družini, doživi nenaden razvoj: iz postranskega lika plašne deklice postane aktivna objokovalka mrtvih ${ }^{6}$ in naposled prostovoljna vodnica in skrbnica svojega očeta Ojdipa. ${ }^{7}$ Ena izmed poglavitnih razlik med Evripidovo in Sofoklovo Antigono je, da je Antigona v Feničankah precej manj vpeta $\mathrm{v}$ ritualno-religiozno sfero, ${ }^{8}$ zato je njena vloga bolj omejena na raven sorodstvene dolžnosti.

Kakor koli že danes vrednotimo Evripidove tragedije, ${ }^{9}$ je njegov ugled v helenistični dobi zasenčil tako Sofokla kot Ajshila. Evripidove drame naj bi namreč bile bližje ljudskemu okusu oziroma okusu (pol) izobražene publike - ne pa tudi intelektualne elite, ki naj bi bolj cenila Sofokla -, zato se je tudi ohranilo več njegovih dram kot od Sofokla in Ajshila skupaj. O Evripidovi popularnosti med drugim pričujejo tudi številni odlomki njegovih tragedij $\mathrm{v}$ raznih antologijah, parodični citati $\mathrm{v}$ poznejših komedijah, številne reference pri mitografih, historiografih, filozofih (Aristotel) in govornikih (Demosten) ter nenazadnje mnoge papirusne najdbe. Evripida je povrhu favoriziral tudi antični izobraževalni sistem, zlasti pouk retorike, pri katerem niso bile toliko pomembne literarne kvalitete, temveč bolj gnomični izrazi in primeri (eksempli), ki se jih je dalo uporabiti v najrazličnejših kontekstih (Mastronarde 4-7).

${ }^{5}$ O Evripidovih Feničankah gl. tudi Kocijančič, Mit o Antigoni 29-30.

${ }^{6}$ Zimmerman (153) ugotavlja, da Antigona postane aktivna šele takrat, ko napol blazna z razpuščenimi lasmi neutolažljivo objokuje svoje mrtve.

${ }^{7}$ Ta nenaden razvoj je nekatere moderne filologe napeljal na misel, da naj bi bilo v tragediji več interpolacij in nepristnih odlomkov (gl. Zimmermann 141-142).

${ }^{8}$ Čeprav je za Evripidovo Antigono dolžnost pokopavanja mrtvih še dojeta kot religiozna zapoved, pa za razliko od Sofoklove nima več absolutne veljave (Zimmermann 155).

9 Še vedno je v strokovni literaturi navzoče mnenje iz časa nemške romantike, ki je v svoji idealizaciji grške klasike tragedijo razumela »organsko«: pri Ajshilu naj bi bila zato tragedija še okorna, nerazvita, pri Sofoklu naj bi dobila popolno harmonijo in celovitost, pri Evripidu pa naj bi že zapadla v dekadenco (Mastronarde 11). 
Kot bomo videli, je bila prav ta posofoklovska podoba Antigone, ki jo predstavlja tudi Evripid, vse do 16. stoletja daleč najvplivnejša. $\mathrm{V}$ poznejši literarni recepciji Antigone lahko zato vse do novega veka prepoznamo velik odmik od Sofoklove izjemno kompleksne dramske upodobitve. Vendar pa Antigona zato dobi nove pomenske plasti, ki so prav tako intrigantne, čeprav na drugačen način.

\section{Latinska Antigona: Seneka in Stacij}

Tudi iz rimskega obdobja je, vsaj kar zadeva mit o Antigoni, veliko izgubljenega. Iz časa rimske republike (2. stoletje pr. Kr.) se nam je pod imenom Lucij Akcij ohranil seznam štirih dram, ki vsebujejo odlomke iz tebanskega mita. Ena od njih se je celo imenovala Antigona. Delo je razen nekaj fragmentov izgubljeno. Skoraj gotovo pa je, da je bilo v povezavi s Sofoklovo istoimensko tragedijo (Zimmermann 235).

Presenetljivo je, da Antigona v avgustejski literaturi skoraj ni navzoča. Na skop odmev naletimo le pri Properciju, in sicer v drugi kitici osme elegije v drugi knjigi (II, 8, verzi 21-24):

quid? non Antigonae tumulo Boetius Haemon

corruit ipse suo saucius ense latus,

et sua cum miserae permiscuit ossa puellae,

qua sine Thebanam noluit ire domum? (Propertius 126)

$\mathrm{Z}$ besedami slovenske prepesnitve:

Kaj? Mar ni si nekoč na grobu Antigone drage

Hajmon, tebanski junak, v prsi porinil svoj meč?

Raje pač svoje kosti pomešal s kostmi je dekleta,

kakor da v Tebe odšel sam bi brez ljube domov. (Propercij 42) ${ }^{10}$

Pesnik je razočaran zaradi nezvestobe in nehvaležnosti svoje ljube (Cintije) in zaradi žalosti pomisli na smrt (samomor), zato primerja svojo situacijo s Hajmonovo (Hemonovo), ki se je zaradi ljubezenskega obupa sam zabodel. Vendar primerjava šepa, saj pesnik (Propercij) v nadaljevanju sugerira, da naj ljubljena umre skupaj z njim (to lahko razumemo, kot da jo hoče pesnik umoriti ali prepričati, da bi skupaj z njim naredila samomor): sed non effugies: mecum moriaris oportet, „Tudi

${ }^{10}$ Za primerjavo dodajam svoj dobesedni, prozni prevod: „Kaj? Ali ni bojotijski Hemon v Antigonini gomili propadel, zaboden v stran s svojim mečem in je svoje kosti pomešal s kostmi svojega dekleta, saj brez nje ni hotel iti na svoj tebanski dom?« 
ti mi, dekle, ne utečeš, z menoj boš umrla« (verz 25, Propercij 42). Kakor koli že, Propercij se vendarle nanaša na ljubezensko zvezo med Antigono in Hajmonom, kar kaže na vpliv Sofoklove Antigone. ${ }^{11}$

Ce rimska zlatodobna Antigona skoraj ne obstaja, pa imamo iz časa srebrnodobne rimske literature dve vrhunski deli, v katerih mit o Antigoni dobi novo literarno podobo, zato si ju velja nekoliko nadrobneje ogledati. To sta Senekova drama Feničanke in Stacijev ep Tebaida.

Senekova tragedija Feničanke (Phoenissae), nastala okrog leta 65, se, kot kaže že naslov, opira na istoimensko Evripidovo tragedijo, deloma pa tudi na Ajshilovo Sedmerico proti Tebam. Senekove tragedije se že po sami zgradbi precej razlikujejo od grških in tudi Feničanke precej odstopajo od Evripidovega zgleda. Vendar ni povsem jasno, koliko je Seneka pri svoji upodobitvi Antigone posegal po izgubljenem gradivu iz helenističnega in rimskega obdobja (von Albrecht 997), koliko pa je njegovo izvirno delo.

Feničanke delujejo precej fragmentarno, ni zbora, prehodi med prizori so abruptni, pa tudi drama sama se abruptno konča, kar daje vtis, da je konec izgubljen. Tragedija je razdeljena na dva dela. V prvem naletimo na dialog med Ojdipom, ki je sam sebe oslepel in odšel v izgnanstvo v Kitajron, in sicer skupaj z Antigono, ki se mu je sama prostovoljno pridružila kot vodnica. Ojdip je spričo svojih zločinov povsem obupan in hoče storiti samomor. Zaveda se, da je povsem kriv (totus nocens sum, verz 156, Seneca 356), zato bi rad končal svoje prekletstvo. Svojo hčer Antigono prosi, naj mu pomaga pri samomoru, kajti tako bo morda lahko preprečil vojaški spopad njegovih sinov. Antigona na to ne pristane, na vsak način ga hoče odvrniti od tega. Ker pa ga s svojimi (precej stoiško intoniranimi) argumenti ne uspe prepričati, nazadnje pade pred njim na kolena in tako s solzami doseže, kar ne more z besedami (verzi 306-319). Ojdip vzklikne: iubente te vel vivet, "zavoljo tvoje prošnje bom živel« (verz 319, Seneca 368).

Odnos med Ojdipom in Antigono je precej intenziven in kompleksen. Seneka je verjetno prvi avtor, ki nakazuje, da je med njima možnost seksualnega razmerja. Težko bi rekli, da gre za de facto incestuoznost, vendar je nevarnost incesta vendarle v zraku. Predvsem je Ojdip tisti, ki se boji, da bi zagrešil incest (Hirschberg 31). ${ }^{12}$ Tako na primer hčerino ljubezen do sebe imenuje amor: quid me, nata, pestifero tenes I

${ }^{11}$ Kot ugotavlja Zimmermann (129), je Sofokles tisti, ki je iznašel lik Hajmona kot Antigoninega zaročenca in je zato domneva, da je ljubezenska zveza med Hajmonom in Antigono obstajala v predtragiški tradiciji, čista domneva.

${ }^{12} \mathrm{Za}$ branje, ki to grožnjo incesta prepoznava tudi pri Antigoni, gl. Donovan Ginsberg 199-230. 
amore vinctum?, "Zakaj se me, hčer, oklepaš s pogubonosno ljubeznijo" (verzi 38-39, Seneca 348). Ojdip se zaradi incesta z materjo zdaj boji novega s hčerjo, zato ji zapove: discede, uirgo: timeo post matrem omnia, "umakni se, devica: po materi se vsega bojim" (verz 50, Seneca 348).

$\mathrm{V}$ drugem delu si Antigona prizadeva rešiti tudi druge člane svoje družine, zato svojo mater Jokasto prosi, naj sinova odvrne od spopada (verzi 403-406). Antigona tu deluje precej avtonomno, skoraj drzno, materi prigovarja, naj pomiri svoja sinova tako, da vstavi svoje gole prsi med njuna sovražna meča (nudum inter enses pectus infestos tene, verz 405, Seneca 376) in naj tako: aut solve bellum, mater, aut prima excipe, "ali ustavi vojno ali pa naj jo prva občuti« (verz 406, Seneca 376).

Antigona je v Senekovi drami zgled hčerinskega spoštovanja in vdanosti do staršev (verz 81isl.), je virgo pia. Ta sintagma sicer nikjer ni uporabljena neposredno, a jo Ojdip vendarle venomer naziva $\mathrm{z}$ virgo in se spričo njene krepostnosti nejeverno vprašuje: aliquis est ex me pius?, "ali je lahko iz mene kaj hvalevrednega" (verz 85 , Seneca 352$).{ }^{13}$ Toda če je kdo pius oz. pia v Ojdipovi družini, potem je to ona: [potes] sola pietatem in domo / docere nostra, "samo ti lahko v naši hiši učiš vdanost / spoštovanje« (verz 310, Seneca 366).

Kljub tej eksaltirani morali je Antigona v svoji pietas naposled neuspešna, tragični konec je neizbežen, sile fatuma so nadmočne. Ojdip na koncu prekolne svoja sinova. Čeprav se drama abruptno konča bodisi, da je to bila Senekova intenca ali pa je konec izgubljen -, je jasno, da je katastrofa neizbežna. Senekova Antigona je zato podvržena silam stoiško koncipiranega kozmosa (Zimmermann 251).

Le nekaj desetletij za Seneko je tebanski mit mojstrsko literarno portretiral Publij Papinij Stacij, v svojem epu Thebais (Tebaida), ki ga sestavlja 12 knjig daktilskih heksametrov. Ep je bil verjetno napisan že v 80. letih po Kr., izšel pa je v začetku 90. let in je takoj postal velika uspešnica.

$\mathrm{Na}$ delo so najbolj vplivali Evripid, Ajshil (morda tudi Sofokles), ${ }^{14}$ Senekove tragedije, Vergilijeva Eneida in Ovidijeve Metamorfoze. Stacij je sicer precej izviren v svoji obdelavi tebanskega mita in vpelje tudi številne nove osebe, vendar se moramo tu omejiti samo na tiste odseke, v katerih nastopa Antigona. Ta je tako kot pri Seneki sicer stranski lik, vendar doživi pomemben razvoj.

${ }^{13}$ Hirschberg (40) ta odlomek razume tako, da Ojdip spričo dejstva, da Fortuna vedno neomajno deluje zoper dinastijo Labdakidov, ne more verjeti v Antigonino pietas, zato ima to za eno izmed zvijač Fortune.

${ }^{14} \mathrm{O}$ morebitnem vplivu Sofokla na Stacija gl. predvsem Heslin, »Statius and The Greek»1-19. 
$\mathrm{Na}$ Antigono naletimo šele v 7. knjigi, ko gre skupaj z Jokasto in Ismeno v tabor argejske vojske, da bi v začasnem premirju med obema vojskama Polinejka odvrnile od tega, da bi vstopil v Tebe (knjiga VII, verzi 475-563). Potem pa jo srečamo še v posebni akciji, ko se samo Jokasta in Antigona odpravita na bojišče spravit Eteokla in Polinejka, preden se spopadeta (knjiga XI, verzi 354-382). Tu je njen govor drzen, skoraj besen, in za hip omehča Polinejka, a vendarle naposled ne doseže svojega namena. Erinije oz. furije so močnejše in tako še z večjo silo spet izvabijo na plan morilski bes iz Polinejka in Eteokla. Antigono zatem srečamo po usodnem medsebojnem poboju obeh bratov, ko pride sama na bojišče, da bi ju objokovala (knjiga XI, verzi 580-633). Sedaj jo spremlja Ojdip, saj izvemo, da je Jokasta med tem v palači naredila samomor.

V 12. knjigi pa Antigono nekoliko zasenči vpeljava nove osebe, to je Argije, Polinejkove žene oziroma vdove. Polinejk se tej, potem ko je že ubit, prikaže in ji naroči, naj pokoplje njegovo truplo. Ta na skrivaj prispe na bojišče pred Tebe in začne objokovati truplo svojega moža. Ker je povsem sama, vzklikne: ubi mater, ubi inclyta fama Antigone?, "Kje mati, kje slavna Antigona?" (knjiga XII, verz 331, Statius 470). Šele zatem prispe tudi Antigona. Argija je ne spozna, zato ji ta smelo pojasni: mea membra tenes, mea funera plangis, "Moje ude držišs, moje truplo objokuješ" (knjiga XII, verz 383, Statius 472). Antigono je sicer sram, ker v svoji sestrski pietas (vdanosti) ni prišla prva $\mathrm{k}$ Polinejku. $\mathrm{V}$ tem lahko razberemo, da je tu amor pred pietas. Erotična ljubezen med ženo in možem je pred sestrsko ali bratsko vdanostjo in spoštovanjem.

Argija in Antigona tako postaneta družabnici v nesreči in žalovanju (sociae malorum). To pa jima, kot ugotavlja Voigt (72), v svetu moških vrednot in moralnem vakuumu bratomorne vojne dopušča, da vendarle postaneta aktivni: in sicer s tem, ko svojo (emocionalno) izkušnjo žalosti povežeta s pravico do ritualnega žalovanja. Prav ta ritualni aspekt, ki je nad zgolj osebno prizadetostjo, podeljuje obema ženskama posebno moč. Ta pa ima $\mathrm{v}$ tem, da ju na neki način rešuje iz paralizirane in docela podrejene vloge žensk ob tragičnem izidu vojne $\mathrm{v}$ patriarhalni družbi, tudi politične momente. Žensko žalovanje služi za »indikator družbe, ki funkcionira, družbe, v kateri je vrednota individuuma in vrednota njegovih oz. njenih odnosov do drugih spoštovana" (Voigt 80 ). To politično opolnomočenje se zelo jasno pokaže malo pozneje, ko se obe ovesta, da sta prekršili Kreontov ukaz. Zato tudi lahko izpričata svoj razlog in temelj prekršitve: »me pietas», "me duxit amor" (knjiga XII, verz 459, Statius 478). Gre za zavesten upor obeh, 
ki pa seveda ima različni gibali. Argijo vodi erotična ljubezen do moža (amor), Antigono sestrska predanost svojemu bratu (pietas). ${ }^{15}$

Konec epa sicer ni tragičen: argejske ženske uspejo prepričati atenskega Tezeja, da zbere svojo vojsko in porazi samodržnega Kreonta. To mu na koncu tudi uspe. Vendar v luči celotnega epa vseeno prevladuje tragično fatalistično vzdušje, saj so vse osebe $\mathrm{v}$ zadnji instanci vendarle podrejene determinizmu usode. Na ravni celote je stoiški pečat dela nespregledljiv.

Kot ugotavlja sodobna filologija, je Stacijev ep izjemno kompleksno delo, v katerem kar mrgoli ambivalenc in paradoksov. Tudi Antigona v njem kaže takšne poteze, saj je razpeta med (relativno) avtonomnostjo ženske, ki lahko vpliva na moške (Polinejka), ima pravico do žalovanja za umrlimi in se je zmožna upreti Kreontovemu ukazu, in tragičnim determinizmom nadmočnih metafizičnih sil (bodisi v obliki furij ali celokupnega fatuma). Takšna ambivalentna podoba Antigone je bila, kot bomo videli, dobra popotnica srednjeveški recepciji.

\section{Srednjeveške Antigone}

Zaradi izgube ogromnega korpusa antičnih besedil ob koncu antike (in začetku "temnega" srednjega veka) je srednjeveška recepcija Antigone večinoma pogojena samo z enim tekstom, in to je prav Stacijeva Tebaida. Zato se raziskava srednjeveških literarnih upodobitev Antigone skoraj v celoti prekriva z raziskavo srednjeveške recepcije tega epa. Vsak govor, vsak tekst, ki v srednjem veku tematizira Antigono, gre nujno skoz Stacijevo sito.

Tebaida je bila skoz ves srednji vek zelo priljubljeno besedilo, kar dokazujejo številne adaptacije tega dela tako v meniškem kot»ljudskem", viteško-dvorskem kontekstu. Prva omemba iz srednjega veka, ki priča o tem, da se je bralo in preučevalo Stacijeva dela, prihaja iz 8. stoletja, in sicer iz kroga meniških pisarjev, ki so delovali v Yorku. Več rokopisov Tebaide, ki ima vsaj dve različni rokopisni liniji, je mogoče datirati v 10. stoletje ali celo še prej, v 9. stoletje. Vsekakor pa je Tebaida (pa tudi Stacijeva delno ohranjena Ahileida) v 10. stoletju že postala del šolskega branja, tako da je bil Stacij na prehodu v drugo tisočletje poleg Vergilija in Ovidija najbolj citiran antični avtor (Brunhölzl 67-68).

${ }^{15}$ Kot ugotavlja Zimmermann (258), sta tako Argija kot Antigona nekakšno utelešenje virtus in pietas - torej obeh pomembnih rimskih vrlin, ki v epu nastopata tudi kot personifikaciji, kot Virtus in Pietas, ki delujeta kot protiutež furijam Tizifoni in Megeri. 
Vsaj tri različne predelave oziroma adaptacije Stacijevega epa so se ohranile na Irskem. Najpomembnejše in najobsežnejše je delo z naslovom Togail na Tebe (Uničenje Teb). Gre za skoraj integralen prozni prevod Tebaide v srednjeveško irščino (t. i. Middle Irish, An MheánGhaeilge). Tu je treba prevod razumeti v okvirih srednjeveških standardov, kar nikoli ne pomeni modernega, natančnega filološkega prevoda, ampak je pisar prevajalec interpretativno interpoliral besedilo z različnimi viri. V primeru omenjenega besedila z odlomki iz komentarja Tebaide iz 4. stoletja, ki ga včasih pripisujejo Laktanciju Placidu, pa tudi - to je bolj presenetljivo - z Ovidijevimi Metamorfozami (Miles 58). Delo je sicer zelo težko natančno datirati, saj je tekstna kritika te vrste srednjeirske proze žal še v povojih, kljub temu ga je mogoče širše umestiti nekje med 10. in 12. stoletje.

Kolikor gre za integralen prevod oz. adaptacijo Tebaide, je skoraj gotovo, da se v tem irskem tekstu pojavi tudi Antigona. Čeprav je zaradi nedostopnosti besedila nemogoče reči, ali gre za kakšna odstopanja od Stacijevega epa ali ne.

Bolj določno presojo lahko podamo pri eni izmed najbolj znanih visokosrednjeveških adaptacij Stacijevega epa, ki sodi v čas oživitve srednjeveškega zanimanja za antiko (medievalisti danes tej pravijo kar renesansa 12. stoletja). Gre za srednjefrancosko delo Roman de Thèbes (Roumanz de Thebes), ki je nastalo približno sredi 12. stoletja, morda izpod rok nekega pisca na dvoru Henrika II. Plantageneta in Eleanore Akvitanske.

Roman de Thèbes francoska literarna veda uvršča v posebno zvrst t. i. romans antiques. Za te je značilno, da adaptirajo antične epe in antično zgodovinsko snov v ljudskem jeziku (francoščini), pri tem pa se opirajo tudi na domačo, francosko herojsko epiko in že nastajajočo viteško-dvorsko kulturo fin amore. Gre za žanr, ki razvojno sodi nekam med chanson de geste in roman courtois, dvorski roman (Edwards 303), po svojem notranjem ustroju pa gre za edinstveno, celo eksperimentalno literarno obliko, ki je vplivala tudi na mnoge druge srednjeveške literarne zvrsti (Battles 20).

Roman o Tebahv osemzložnih rimanih kupletih izvirno preoblikuje antično mitološko in zgodovinsko snov iz tebanskega mita (poglavitni vzor je seveda Stacij) in jo prireja skladno novemu srednjeveškemu fevdalnemu okvirju. Zato deluje anahronistično: kljub antičnim krajem in osebam je ozračje pogosto povsem viteško-dvorsko in ponekod celo križarsko obarvano. Kot tak je bil seveda namenjen predvsem kleriško-dvorskemu občinstvu.

Tako kot pri Stacijevi Tebaidi je tudi v Romanu o Tebah Antigona stranski lik, vendar ima tu skoraj povsem drugačno vlogo. Tu ni 
več sledu o žalovanju nad mrtvim Polinejkom, niti ne o nepokorščini zakonu, saj Antigona nastopa kot prelepa dvorna dama, ${ }^{16}$ kateri je vdan in ji služi argejski junak oziroma, bolje, vitez Partonopeks (Parthonopiex). Gre za čisto iznajdbo anonimnega avtorja, ki Antigono vpne v okvir ljubezenskega kodeksa dvorske ljubezni (Battles 36). ${ }^{17}$ Njena precej stranska vloga se zaključi tako, da umre od žalosti, ko Partenopeks pade v boju in ga slovesno pokopljejo v Tebah. Za razliko od rimskega Stacija je Antigona v tem delu povsem pasivizirana in marginalizirana. ${ }^{18}$

Zaradi izjemne avtoritete Stacija v celotnem srednjem veku niti ne preseneča, da se rimski pesnik - kot literarna persona - pojavi tudi $\mathrm{v}$ Dantejevi Božanski komediji. Najdemo ga v 21. spevu Vic, ko se pridruži Danteju in Vergiliju in da nekakšen hommage slednjemu. To, kar preseneti, je, da Dante Stacija naredi za kristjana, ki naj bi ga k tej veri nagnila prav Vergilijeva 4. ekloga, včasih imenovana tudi »mesijanska«. Kako pomemben je za Danteja Stacij, kaže tudi dejstvo, da ga spremlja do zemeljskega raja na vrhu gore v vicah, potem ko se mora Vergilij že vrniti v Limb. Dante s tem Stacija na neki način postavi višje od Vergilija - ta naj bi kljub svojemu neprekosljivemu pesniškemu geniju vendarle razkrival omejenost poganske modrosti in luči naravnega razuma, ki še nista očiščena $s$ krščanskim razodetjem (Heslin, "Statius in Dante's« 517).

Antigona je v Božanski komediji zelo bežno omenjena v 22. spevu Vic, ko Stacij vpraša Vergilija, kateri plemeniti pogani prebivajo z njim v Limbu. Vergilij med drugim našteje tudi ženske mitske junakinje iz Tebaide:

Quivi si veggion de le genti tue,

Antigonè, Deifilè e Argia,

e Ismenè sí trista come fue. (knjiga XXII, verzi 109-111, Dante, La Divina 249)

${ }^{16}$ Pripovedovalec natančno opiše njeno lepoto in jo primerja $s$ »kraljevsko hčerjo» (prim. verze 4045-4084, Le Roman 127-128).

${ }^{17}$ Erotika fin amor(e) se bolje pokaže pri Ismeni, ki iskreno izpove hrepenenje po svojemu vitezu Atisu: Ou face bien ou ge foloi, I coucherai moi o lui, ce croi, "najsi ravnam dobro ali bedasto, bom šla z njim v posteljo, to verjamem« (verzi 4692-4693, Le Roman 147).

${ }^{18}$ To delo pa je, poleg Tebaide, tudi samo služilo kot predloga drugim podobnim spisom; eden izmed bolj znanih je delo The Siege of Thebes (ok. 1422), ki ga je angleški avtor John Lydgate priredil za poznosrednjeveško angleško občinstvo in ga začinil s precejšnim moraliziranjem. Kar zadeva Antigono, ni v njem ničesar novega. 
To se v prepesnitvi Andreja Capudra sliši takole:

Junakinj tvojih ta dolina hrani:

Antígono, Deifílo in Argíjo

in Ízmeno, ki še ječi ob rani. (Dante, Božanska 110) ${ }^{19}$

Antigona, ki je tu zgolj omenjena, se nahaja v družbi s sestro Ismeno, Polinejkovo vdovo Argijo in Deifilo, ženo argejskega junaka Tideja in Argijino sestro. Antigona je torej tu zgolj ime krepostne ženske, ki si je zaslužila svoj košček Limba, in nič več. Čeprav je ta omemba zelo skopa, pa je vendarle poveden sam kontekst: vsi moški iz Limba, ki jih Vergilij našteva, so različni starodavni pesniki (med njimi od grških tragedov Evripid), vse ženske pa so samo iz Stacijeve Tebaide, ki so tako na neki način prepoznane kot resnične protagonistke epa in zato tudi povzdignjene na raven najbolj krepostnih antičnih žena. In Antigona je (samo) ena izmed njih.

$\mathrm{Na}$ podobne, zelo bežne omembe Antigone naletimo tudi pri Boccacciu. Predvsem v njegovem epu Teseida (izšla leta 1339) - na katerega je močno vplival tudi Roman o Tebah - in v njegovem znanem traktatu De claris mulieribus (O slavnih ženah, leta 1362), zbirki biografij zgodovinskih in mitoloških žensk. Čeprav je tu Antigona omenjena v 23. in 27. poglavju, vendarle v oči bije dejstvo, da si samostojnega poglavja pri Boccacciu niti ni zaslužila. $\mathrm{Na}$ drobno omembo naletimo tudi v njegovem spisu Genealogiae Deorum Gentilium (2,71), v katerem je rečeno, da je Antigona skupaj z Argijo pokopala oba brata in so jo nato umorili - različica, ki je pri Staciju ni (Söffner 85).

Srednji vek je pritegovala tudi neka druga Antigona, morda celo še bolj kot tebanska - trojanska Antigona. Ta je precej minoren lik $\mathrm{v}$ antični mitologiji: bila je hčer trojanska kralja Laomedona in sestra kralja Priama (zadnjega kralja Troje), ki je slovela po svoji lepoti, a vendar tudi ošabnosti. Posebej naj bi bili lepi njeni lasje, zaradi katerih je trdila, da je lepša od boginje Here (Junone). Zato jo je boginja kaznovala tako, da je njene lase spremenila $v$ kače. Kasneje se jo je neki drug bog usmilil in jo spremenil v štorkljo. Poglavitni vir za to so Ovidijeve Metamorfoze 6, 93-95 (Hard 139). ${ }^{20}$

${ }^{19}$ Podajam še svoj dobesedni prevod: »Tam je od tvojega ljudstva videti: Antigono, Deifilo in Argijo, in Ismeno, tako žalostno, kakor je bila.»

${ }^{20}[\ldots]$ pinxit et Antigonen, ausam contendere quondam / cum magni consorte Iovis, quam regia Iuno / in volucrem vertit ..., "... in upodablja Antigono, kako si je nekoč drznila zoperstaviti soprogi velikega Jupitra, in kako jo je kraljica Junona spremenila v ptico ..." (Ovid 294). Malo pozneje izvemo, da gre za štorkljo (ciconia). 
Resnici na ljubo v srednjeveški tekstih včasih niti ni mogoče ugotoviti, za katero Antigono dejansko gre. $S$ tem v zvezi velja omeniti vsaj še dve srednjeveški deli. V 12. stoletju naletimo na omembo Antigone tudi $\mathrm{v}$ trubadurski liriki, in sicer $\mathrm{v}$ delu manj znanega provansalskega trubadurja Arnauta de Mareuila. Ohranjenih je 25 njegovih pesmi v obliki cansa ter pet ljubezenskih pisem. V enem izmed teh med drugimi močno hvali lepoto Antigone (Steiner 195). Tu gre skoraj gotovo za trojansko Antigono, saj je to njen tipičen atribut, medtem ko nikjer $\mathrm{v}$ antiki ni govora o lepoti tebanske Antigone. ${ }^{21}$

Steiner (195) omenja, da se Antigona pojavi tudi pri Christine de Pisan, in sicer v njenem delu Cent histoyres de Troie (Sto trojanskih zgodb) iz leta 1400, sicer bolj znanem pod imenom L'Épistre de Othéa (Othejino pismo). Gre za didaktično delo iz zvrsti t. i. miroir de princes, ki je namenjena moralnemu poduku mladih princev. Delo je zasnovano kot pismo Otheje, povsem izmišljene osebe, trojanskemu Hektorju. Tudi v tem delu je Antigona le bežno omenjena in niti ni jasno, za katero Antigono gre, najverjetneje za trojansko. ${ }^{22}$

V srednjem veku smo pogosto priča kontaminaciji (contaminatio) mitoloških izročil, ki v eni mitski osebi lahko komprimirajo več drugih, kar pa povzroča številne nejasnosti in dvoumnosti, in lik Antigone ni tu nobena izjema. Takšen primer, pri katerem dejansko ne vemo, za katero Antigono dejansko gre, tebansko ali trojansko (ali celo obe hkrati), se morda najizraziteje pokaže v delu Troilus and Criseyde (Troil in Kresida) izpod peresa Geoffreyja Chaucerja, enega največjih angleških srednjeveških literatov. Gre za delo, ki se navdihuje pri Boccaccievi pesnitvi Il Filostrato ${ }^{23}$ - oboje pa je gradivo za Shakespearjevo dramo Troilus and Cressida.

Antigona je tudi pri Chaucerju stranska oseba, pojavi se v drugi knjigi, prizor pa velja za Chaucerjevo lastno iznajdbo, saj tega prizora v Boccaccievem Filostratu ni. Tu naletimo na Hrizeido oz. Kresido (Criseyde), ki potem, ko je izvedela, da se je Troil na smrt zaljubil vanjo, omahuje med strahom in hrepenenjem po ljubezni. Sprehaja se po svojem vrtu in nato zasliši svoje nečakinjo (niece) Antigono, ki zapoje pesem, nekakšno hvalnico ljubezni, in tako pomaga svoji teti, da premaga svoje strahove ter se odloči za ljubezen (knjiga II, verzi 899-903).

${ }^{21}$ Delo mi žal ni bilo na voljo. Dostopne antologije trubadurske lirike pa te pesmi ne uvrščajo v izbor.

${ }^{22}$ Tudi to delo mi ni bilo na voljo.

${ }^{23}$ Ta je spet adaptacija francoskega roman antique iz 12. stoletja, Roman o Troji (Le Roman de Troie), ki ga je napisal Benoît de Sainte-Maure. 
Tu ni jasno, ali je zares mišljena Antigona kot Ojdipova hči (in gre tako za nekakšno trojansko-tebansko povezavo) ali pa gre za trojansko Antigono kot hčer (oziroma, po drugi razlagi, vnukinjo) trojanskega kralja Laomedona. Čeprav je lepota izrazit atribut trojanske Antigone, pa to gotovo ni krepostnost in plemenitost, ki jo kaže Chaucerjeva Antigona. Po drugi strani, spet, ni v tem prizoru ničesar, kar bi spominjalo na Ojdipovo hči, ki jo poznamo iz Stacijeve Tebaide. Chaucerjeva Antigona $\mathrm{v}$ tipično dvorskem prizoru morda še najbolj spominja na prav tako samosvojo podobo Antigone iz Romana o Tebah.

Čeprav v tekstu ni dovolj indicev, da bi Antigono zanesljivo postavili v prepoznaven mitsko-historičen kontekst (Battles 125), je vendarle treba poudariti izvirno zasnovo Chaucerjeve literarne upodobitve. Če je bila dvorska ljubezen v srednjem veku tipično "moška zadeva", pri kateri so izvoljene ženske večinoma pasivne, zreducirane zgolj na ljubezenski »objekt «, je pri Chaucerju drugače. Antigonina malone ekstatična pesem o moči ljubezni, ki ji je tudi sama notranje zavezana, govori o "močnem« subjektu, o dejavnem glasu ženske ljubezni, ki odstopa od srednjeveške konvencionalnosti (Behrman 322-323); še več, v svojem izpovedovanju pristnega čustvovanja se skoraj približa nekakšni protoromantični intimnosti. Chaucer na ta način ustvari lik Antigone, ki je po svoji aktivnosti in avtonomnosti strukturno podobna antični, pa čeprav na poseben, samosvoj način $\mathrm{v}$ okviru druge in drugačne dobe srednjeveškega fevdalizma.

\section{Sklep: od humanizma do danes in nazaj}

$\mathrm{Z}$ renesančnim humanizmom, na začetku 16 . stoletja, ko znova postanejo dostopni izvirniki grške tragedije (in nastanejo njihovi prevodi v latinščino ter ljudske jezike), recepcija Antigone doživi nov velik razcvet. Ta zgodba je dobro znana in raziskana, tako da tu samo nekaj kratkih pripomb.

Humanistična Antigona se od "naše«, moderne Antigone, kot jo poznamo vsaj od konca 18. stoletja naprej, vendarle precej razlikuje. Humanizem je ubral samosvojo recepcijsko pot, ki pa po strukturni logiki ni dosti drugačna od srednjeveške. Antigona je v ozračju humanizma pogosto predstavljena $\mathrm{v}$ svoji idealizirani predanosti in pobožnosti (piété), ki kaže na kristjanizacijo, točneje, na približevanje krščanskemu mučeniškemu liku, kot ga je na sledi Seneki prvi tematiziral že Petrarka v svojih Familiares (Söffner 86). Novo odkritje Antigone je, kljub restituciji besedil antične tragedije, podobno kot $\mathrm{v}$ srednjem 
veku obeleženo s contaminatio izročil in neizogibno domestifikacijo. Če se omejimo samo na najbolj znane literarne prikaze mita o Antigoni $\mathrm{v}$ novoveški literaturi od humanizma do razsvetljenstva, ${ }^{24}$ je njihov skupni imenovalec na dlani: osebe iz antične tragedije so koncipirane kot nekakšni liki iz moralitete, kot moralični zgledi, ki jih je treba posnemati ali pa se jim ogibati. Antigona je tako večinoma prikazana kot vzvišen moralni lik, kot nekakšna sveta devica in celo mučenica za višje ideale ter je zato vredna posnemanja.

Kot opozarja Miola v navezavi na Sofoklovo Antigono, ki je bila od leta 1502 po dolgih stoletjih znova na voljo, je večina zgodnjenovoveških komentatorjev in prevajalcev čutila globoko nelagodje do Antigone (Miola 222). Humanistična recepcija se je bila le stežka zmožna izviti iz moralično-didaktičnega primeža, zato ni bila kos Antigonini etični paradoksnosti. Antigonin lik iz grške tragedije naj bi bil zato bistveno sploščen: "Mogočni literarni, moralni in kulturni imperativi so takrat zahtevali moralne gotovosti in praktične eksemple iz antične tragedije, in ne etične ambivalence, prikaza univerzalnih človeških konfliktov« (Miola 223).

Vendar je to samo pol resnice oziroma je takšno razumevanje recepcije neke pretekle dobe nujno enostransko, saj ne vključuje zavesti o tem, da je bilo neko besedilo "živo «" prav v okviru neke druge in drugačne dobe (ki ni "naša», sodobna). Kritika anahronističnega razumevanja neke pretekle recepcije literarnega dela lahko tudi sama kaj hitro postane anahronistična, če nekritično in nereflektirano vnaša moderne oz. sodobne interpretativne horizonte $\mathrm{v}$ drugo, se pravi preteklo dobo. To se lahko pokaže na primer že $\mathrm{v}$ apriornem favoriziranju filološke »eksaktnosti« pri poznavanju besedila, če si potem na podlagi tega nekritično domišljamo, da je to zadostni pogoj za »boljše poznavanje« besedila od tradicije oz. od konkretnih preteklih recepcijskih horizontov. Tudi s podobami Antigone v 20. stoletju in naprej, do danes, ni nič drugače. Po eni strani so te sicer izjemno polifone in pluralistične, po drugi pa se vendarle ni mogoče ubraniti vtisu, da so v

${ }^{24}$ Najpomembnejši avtorji in literarna dela, ki tematizirajo mit o Antigoni v tem obdobju so: Robert Garnier, Antigone ou la Pieté (1580), Jean Rotrou, Antigone (1638), Jean Racine, La Thébaïde (1664) in Vittorio Alfieri, Antigone (1776).

${ }^{25}$ Podobno poudarja Senegačnik v zvezi s humanističnimi prevodi Sofoklovih del: "Za humanistične prevajalce Antigona (in vsa Sofoklova dramatika) ni bila (zgolj) predmet filološke analize, temveč besedilo, ki (naj) ima poetične, predvsem pa etične učinke tudi v njihovem lastnem času. [...] Verjeli so, da (lahko) prevodi učinkujejo tako, kot je po njihovih predstavah učinkoval izvirnik, kar z drugimi besedami pomeni: verjeli so, da so ta besedila (lahko) živa« (Senegačnik 175). 
ospredju tiste interpretacije (in domestifikacije), ki v Antigoni prepoznavajo arhetip sodobne neustrašne ženske heroine, neomajne borke za vse ponižane in razžaljene, revolucionarke, utelešenja ženske politične revolte itn. Takšne razlage so povsem legitimne, če se le zavedajo svoje zgodovinske pogojenosti - prav tako kot so zgodovinsko pogojene (in legitimne) podobe Antigone kot stoiške "vdane device", pasivne srednjeveške dvorske dame ali krščansko-humanistične "svete mučenice». Vse to so povsem legitimna branja v nenehno - že 2500 let (!) - trajajočem razvoju izjemne zgodbe, ki se ji reče recepcija mita o Antigoni. Pluralizem interpretacij nikakor ni problematičen, problematično je nekaj drugega: namreč to, če kot »strokovnjaki« - filologi, literarni zgodovinarji, kulturni zgodovinarji itn. - povsem nekritično in nehermenevtično relegiramo ogromen korpus recepcijskih odmevov v literaturi nekega celotnega obdobja na smetišče literarne in kulturne recepcije; ${ }^{26}$ če imamo, na primer, neki srednjeveški "roman", kakršen je Roman o Tebah kratko malo za - nonšalantno rečeno - »bizarnega«, oziroma če $\mathrm{v}$ tem (in podobnih delih) ob pomoči razgrnitve najširšega družbenega in literarnega konteksta nikakor ne moremo niti zaslutiti, da gre lahko za "eksperimentalni« roman, ki iznajdeva nove recepcijske možnosti literature prejšnjih obdobij in eksperimentira z novimi izkušnjami in identitetami v okviru svojega prostora in časa. Drugost in drugačnost "tujega", zlasti zgodovinsko bolj oddaljenega, kot je antika in srednji vek, je pri raziskovanju literarne recepcije vselej treba jemati resno, če se nočemo ujeti v past, ki je vsaj pri raziskovanju vpliva mita o Antigoni tako pogosta, namreč $\mathrm{v}$ "projekcijo neustreznih literarnih konceptov $\mathrm{v}$ antiko« (Kocijančič, Kdo 17). Preiskovanje dolge verige recepcije je zato vedno vaja v tem, da bi razumeli svojo pogojenost. "Čiste«, »izvirne« in "prave" Antigone ni: Antigona je že vedno nepreklicno adaptirana, posredovana $\mathrm{z}$ mogočnim plazom tradicije. Povedano $\mathrm{z}$ besedami Mee in Foley, ki v navezavi na sodobne literarne in odrske "rimejke» Antigone poantirano ugotavljata: »Antigona je bila vselej že adaptirana. Sodobna tradicija adaptacij, rimejkov in remiksov zgodb, osnovanih na grških mitih, ustreza temu, kar so že v antiki razumeli kot tradicijo v nenehnem razvoju $\aleph^{27}$ (Mee in Foley 6-7).

${ }^{26} \mathrm{~V}$ to smer nevarno zakorači Fraisse, ko pravi, da Antigona pred 19. stoletjem bolj sodi v hagiografijo kot pa v dramsko zvrst (Fraisse 15-16).

27 "Antigone has always been already adapted, and the current tradition of adapting, remaking, and remixing stories based on Greek myths thus corresponds to what was, even in Antiquity, understood to be a continuously evolving tradition." 
Ajshil. Sedmerica proti Tebam. Prev. Alojz Rebula. Maribor: Študentska založba Litera, 2010.

Dante Alighieri. La Divina Commedia. Purgatorio. Izd. Natalino Sapegno. Firenze: La Nuova Italia, 1990.

Dante Alighieri. Božanska komedija. II. del, Vice. Prev. Andrej Capuder. Maribor: Obzorja, 1972.

Chaucer, Geoffrey. Troilus and Cryseide. Prev. in op. Barry Windeatt. Oxford: Oxford University Press, 1998.

Euripides. Bakhe, Alkestis, Feničanke. Prev. Anton Sovrè. Ljubljana: Državna založba Slovenije, 1960.

Le Roman de Thèbes. 2. zv. Izd. Guy Raynaud de Lage. Pariz: Honoré Champion, 1969.

Ovid. Metamorphoses. Vol. 1. Izd. in prev. Frank Justus Miller. Cambridge, MA: Harvard University Press, 1971 (Loeb 42).

Propertius. Elegies. Izd. in prev. G. P. Goold. Cambridge, MA, London: Harvard University Press, 1990 (Loeb 18).

Propercij. Prev. Kajetan Gantar in Jože Mlinarič. Ljubljana: Mladinska knjiga, 1971 (Zbirka Lirika).

Seneca. Tragedies II: Agamemnon, Thyestes, Hercules Oetaeus, Phoenissae, Octavia. Izd. in prev. Frank Justus Miller. Cambridge, MA: Harvard University Press, 1968 (Loeb 78).

Statius. Thebais. 2 zv. Izd. in prev. J. H. Mozley. Cambridge, MA, London: Harvard University Press, 1928 (Loeb Classical Library).

Sophocles. Antigone. Izd. Mark Griffith. Cambridge: Cambridge University Press, 1999.

Sofokles. Antigona. Prev. Kajetan Gantar (pregl. in dop. prevod). Ljubljana: SNG Drama Ljubljana, 2017.

\section{LITERATURA}

Battles, Dominique. The Medieval Tradition of Thebes: History and Narrative in the Roman de Thèbes, Boccacio, Chaucer, and Lydgate. New York, NY: Routledge, 2004.

Behrman, Mary. »Heroic Criseyde«. The Chaucer Review 38.4 (2004): 314-336.

Brunhölzl, Franz. "Statius in MA«. Lexikon des Mittelalters. VIII: Stadt (Byzantinisches Reich) bis Werl. Stuttgart: Metzler, 1999. 67-68.

Donovan Ginsberg, Laura. "Don't Stand So Close to Me: Antigone's Pietas in Seneca's Phoenissae". Transactions of the American Philological Association 145.1 (2015): 199-230.

Edwards, Robert R. "Medieval Statius: Belatedness and Authority«. Brill's Companion to Statius. Ur. W. J. Dominik, C. E. Newlands in K. Gervais. Leiden, Boston, MA: Brill, 2015. 497-511.

Fraisse, Simone. Le mythe d'Antigone. Pariz: Armand Colin, 1974.

Griffith, Mark. »Introduction«. Antigone. Sophocles. Izd. Mark Griffith. Cambridge: Cambridge University Press, 1999. 1-70.

Heslin, Peter. "Statius in Dante's Commedia». Brill's Companion to Statius. Ur. W. J. Dominik, C. E. Newlands in K. Gervais. Leiden, Boston, MA: Brill, 2015. 512-526. 
Heslin, Peter. "Statius and the Greek Tragedians on Athens, Thebes and Rome«. The Poetry of Statius. Ur. R. R. Nauta, H.-J. van Dam in J. J. L. Smolenaars. Leiden: Brill, 2008. 111-128.

Hirschberg, Theo. Senecas Phoenissen. Einleitung und Kommentar. Berlin, New York, NY: Walter de Gruyter, 1989.

Kocijančič, Matic. "Kdo ni pokopal Polinejka? Skrivnost dvojnega pokopa v Sofoklovi Antigoni«. Primerjalna književnost 41.1 (2019): 9-27.

Kocijančič, Matic. Mit o Antigoni v povojni slovenski književnosti, filozofiji in družbenopolitičnem diskurzu. Doktorska disertacija. Ljubljana: Univerza v Ljubljani, Filozofska fakulteta, 2020."

Mastronarde, Donald J. The Art of Euripides. Dramatic Technique and Social Context. Cambridge: Cambridge University Press, 2010.

Miles, Brent. Heroic Saga and Classical Epic in Medieval Ireland. Cambridge: D. S. Brewer, 2011.

Miola, Robert S. „Early Modern Antigones: Receptions, Refractions«. Classical Receptions Journal 6.2 (2014): 221-244.

Mee, Erin B., in Helene P. Foley. "Mobilizing Antigone«. Antigone on the Contemporary World Stage. Ur. Erin B. Mee in Helene P. Foley. Oxford: Oxford University Press, 2011. 1-47.

O'Connor, Ralph. »Irish narrative literature and the Classical tradition, 900-1300«. Classical Literature and Learning in Medieval Irish Narrative. Ur. Ralph O'Connor. Cambridge: D. S. Brewer, 2014. 1-24.

Senegačnik, Brane. "Humanistična branja Sofoklove Antigone in humanistično razumevanje humanega". Primerjalna književnost 41.2 (2018): 169-189.

Steiner, George. Antigones: The Antigone Myth in Western Literature, Art, and Thought. Oxford: Oxford University Press, 1984.

Söffner, Jan. "Antigone«. Mythenrezeption. Die antike Mythologie in Literatur, Musik und Kunst von den Anfängen bis zur Gegenwart. Ur. Maria Moog-Grünewald. Stuttgart, Weimar: Metzler, 2008. 81-96.

Hard, Robin. The Routledge Handbook of Greek Mythology. Based on H. J. Rose's Handbook of Greek Mythology. London: Routledge, 2004.

Voigt, Astrid. »The Power of the Grieving Mind: Female Lament in Statius's Thebaid». Illinois Classical Studies 41.1 (2016): 59-84.

von Albrecht, Michael. Geschichte der römischen Literatur. Von Andronicus bis Boethius und ihr Fortwirken. 3. razšir. izd. Berlin: Walter de Gruyter, 2012.

Zimmermann, Christiane. Der Antigone-Mythos in der antiken Literatur und Kunst. Tübingen: Gunter Narr Verlag, 1993. 


\section{The Figure of Antigone in Premodern Literature}

Keywords: ancient literature / medieval literature / tragedy / literary characters / Antigone / Sophocles / Euripides / Seneca / Statius / Dante / Chaucer, Gottfried / literary reception

The article examines the figure of Antigone in European literature from antiquity to the end of the Middle Ages. After the period of classical Greek tragedy (Aeschylus, Sophocles, Euripides), Antigone as a literary figure undergoes the most significant adaptation in the Roman era, in Seneca's tragedy The Phoenician Women and Statius's epic Thebaid. In both works, Antigone is marked by Stoic determinism despite her rather active role. In the Middle Ages Antigone was a rather marginal literary figure. She is encountered mainly in the more or less free adaptations of Statius's Thebaid, such as the medieval Irish prose work Togail na Tebe (The Destruction of Thebes) and the French epic Roman de Thèbes. Sporadic mentions of Antigone are also found in Dante, Boccaccio, and Christine de Pizan. The article notes that in medieval literature the thematization of Antigone is often characterized by an interweaving of two mythological figures (and traditions), the Theban and the (much less well-known) Trojan Antigone. Such literary contaminatio (contamination) of the two Antigones is most prominent in Chaucer's epic Troilus and Criseyde. Finally, the discussion touches on the humanist reception of Antigone and draws attention to the hermeneutical problem of the literary reception of Antigone in general.

1.01 Izvirni znanstveni članek / Original scientific article

UDK 821.14'02.09

$821.124^{\prime} 02.09$

82.091"4/14"

DOI: https://doi.org/10.3986/pkn.v44.i1.05 